\title{
Nursing Leadership Models Development In 13 Class A Hospital Ward In Indonesia
}

\author{
Johan Tri Agus Yuswanto ${ }^{1}$, Rita Yulifah ${ }^{2}$, Elly Nurrachmah ${ }^{3}$, \\ Ratna Sitorus ${ }^{4}$ and Ede Surya Darmawan ${ }^{5}$. \\ ${ }^{I}$ Nursing Doctoral Students of the University of Indonesia. \\ ${ }^{2}$ Politechnic Health, Republic ofIndonesia. \\ ${ }^{3,4}$ Faculty of Nursing, University of Indonesia. \\ ${ }^{5}$ Faculty of Public Health, University of Indonesia
}

\begin{abstract}
Head nurse leadership is needed to improve nurse practitioner working performance. Nowadays, there is no such optimal leadership model in Indonesia based on staffs' trust and any other involving part which effectively applicable in hospital ward, that results on good organization performance and high quality health care services. This research was conducted to identify relating consept in order to develop nursing leadership model in class A-hospital ward in Indonesia. This research was conducted by using qualitative and quatitative method with cross sectional design. Sample in qualitative research is six people, while 450 head nurserespondents were involved in quantitative one. This research shows synthesize of five leadership model in literatur, which are effective, transformational, transactional, visioner and servant leadership model, supports Indonesia nursing leadership model plan which can be leadership model alternative for head nurse in class Ahospital in Indonesia.

Expected head nurse attitude are good coach for staff, providing challenge and significany of staff's working performance, team-bulding and team-work, define and arrange group interaction, organize group activities in order to reach organization goal and know staff's need.
\end{abstract}

Key word: nursing leadership model, class A-hospital ward in Indonesia

Submitted Date 02 Jan 2013

Accepted Date: 07 Jan 2013

\section{Introduction}

Health care provided in hospital is integral part of health service as a whole in Indonesia. Great opportunity for 13 class A-hospitals to be world class hospital stimulates the hospital officers to pay more attention on every single health care service in each hospital. Nowadays, health care in hospital tends to be patient-focus and patient safety. There are some cases related to lack patient-focused care which was predicted as a cause of this problem on following research (Wulandari, 2009; Rosalina, 2010; Zaluchu, dkk, 2010; Cahyono, 2011). Next, there were some cases of miss-patient safety which has been compiled by WHO on 2004 in USA, UK, Denmark and Australia. These cases found undesirable event range in 3,2-16,6\%. Those data expected become a precipitate any country to do research and development of Patient Safety Sistem as soon as possible (DepKes, 2006). In addition, there were report of health care officer negligence, particularly nurses (Delima 2008) which found unoptimal role and function of nurses. Furthermore, based on Depkes (2006), $28,3 \%$ from the whole incidents, patient safety issue has been a big problem for nurses. Lack patient focused care and fall to maintain patient safety predicted as source of nurse practitioners' poor working performance to deliver best health care. This condition is an effect of head nurse's poor leadership skill to lead, motivate and do clinical supervision which is caused by inappropriate leadership model application (Anikmah, 2008; Hidayati, 2008). Based on that circumstance, more applicable nursing leadership model is needed for head nurse to improve nurse practitioners working performance which expected increasing nursing care quality. Nowadays, there is no standard nursing leadership model which is scientifically proven give positive effect for nurse practitioners to improve nursing care quality.

\section{General Objective}

The purpose of this study was to obtain effective and applicable nursing leadership model for the whole class A-hospitals in Indonesia.

\section{Specific Objective}

1. To identify consept and construction which involve any leadership model by literature study.

2. To identify concept and construction leadership model that expected by stakeholder to head nurse do.

3. To validate founded consept, then arranged leadership model plan by any expertise. 
4. To develop nursing leadership model.

\section{Study use}

\section{Teoritical Benefit:}

This study was conducted to be a fundamental of nursing management, particularly leadership aspect which appropriate into ward

\section{Applicative Benefit}

a. For health care services in hospital:

The result of this study expected to empower head nurse in hospital for improving nurse practitioner working performance and patient satisfaction. It can be refference for head nurse enrich nurses' motivation for better working performance.

\section{b. For nursing educational institution:}

The result of this study expected to be a basis for expanding material on nursing leadership curriculum and applicable for nursing student in practical field. Effective leadership model may be a nationally standardize nursing leadership model.

\section{c. For nursing management research:}

A fundamental to develop another nursing management research, particularly on effective leadership in any specific health care institution, such as psychiatric hospital, cardiology hospital, cancer hospital, respiratory hospital, etc.

\section{Methodological Benefit}

Base and refference for following research related to function, role and leadership style and model.

\section{a. Design :}

\section{Method}

A development research consisted of two stages, as first stage is literature study, qualitative study and expertise analysis. Literature study aims to find consept or construct leadership theory and leadership model by eksplorative design from nursing books and journal. Qualitative study aims to find consept or construct leadership model which expected by stakeholder to head nurse do, by descriptive phenomenology design with indepth interview. Expertise analysis aims to get input of consept / variable related to developed leadership model.

On the second stage, quantitative study Development Leadership Model done by design. This study classified as quantitative study developmental research by cross sectional approach.

Complete framework can be seen in picture 1:

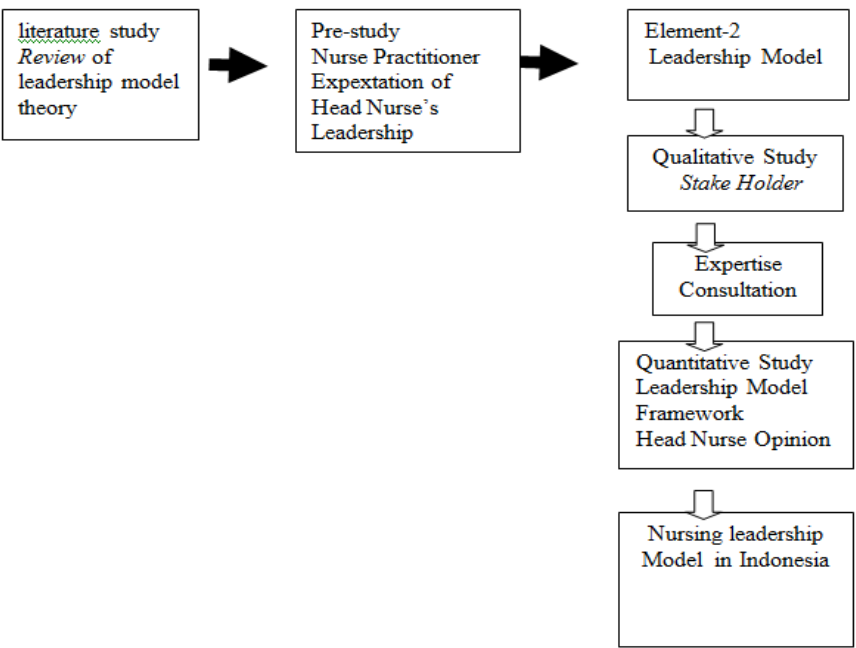

Picture 1. Research Framework

\section{b. Research sample}

Sample on this research consisted of six people for qualitative study from three nursing stakeholder: 3 participants from PPNI and 3 participants from Nursing Care Directory of Indonesia Health Ministry. In other 
hand, sample of quantitative research consists of 450 head nurse respondents in 13 class A-Hospital in Indonesia.

\section{c. Data analysis}

Qualitative analysis uses Colaizzi descriptive phenomenology analysis, while quantitative research uses SEM (Structural Equation Modeling) with Confirmatory Factor analyze.

\section{Result 1st Stage Study (Qualitative)}

\section{Results}

a. Requirements for Head Nurse of Class A Hospital:

1) Graduate from bachelor degree (NERS)

2) Sufficient experience, no novice

3) Passed on leadership management course

4) Nursing leadership management certificate holder

5) Passed on specific managerial skill competency examination

6) Own PPNI-recomended carrier pathway

7) Chosen by staff suggestion

8) Discipline, good attitude and communication.

b. Function and role of Head Nurse Class A Hospital is running management function and head nurse role.

c. Leadership style. Class A hospital

1) Current leadership style of head nurse is otoriter and democratic

2) Recommended leadership style is situational leadership style.

d. Leadership Model. Class A Hospital

1) Leadership model is very needed

2) Recomended leadership model is transactional, transformational, servant leadership, effective visioner, and compilation/synthesize some models.

\section{Result 2nd Stage Study (Quantitative)}

a. Univariate analysis

A univariat analysis in demography caracteristic of head nurse shows that most of them are women, range in 36-45 years old, married, bachelor degree, Javanese, well-trained especially on ward management training, 16-30 years old working experience with 1-5 years working experience as a head nurse.

\section{b. Bivariate analysis}

Relation between leadership model elements and Indonesia nursing leadership model.

Table 1. Relation between leadership model elements and Indonesia nursing leadership model

\begin{tabular}{|c|c|c|}
\hline \multirow{2}{*}{ Element model } & \multicolumn{2}{|c|}{ Indonesia Nursing Leadership } \\
\hline & Corelation Coefficient & p-value \\
\hline \multicolumn{3}{|l|}{ Effective } \\
\hline 1. Institutional & 0,723 & 0,005 \\
\hline 2. Consideration & 0,692 & 0,005 \\
\hline \multicolumn{3}{|l|}{ Transformasional } \\
\hline 1. Idealized Influence & 0,734 & 0,005 \\
\hline 2. Inspirational Motivational. & 0,787 & 0,005 \\
\hline 3. Intelectual Stimulation & 0,744 & 0,005 \\
\hline 4. Individualized Consideration & 0,770 & 0,005 \\
\hline \multicolumn{3}{|l|}{ Transactional } \\
\hline 1.Knowing staffs' need & 0,633 & 0,005 \\
\hline 2.Good communication skill & 0,343 & 0,005 \\
\hline 3.Responsive to staffs' need & 0,486 & 0,005 \\
\hline \multicolumn{3}{|l|}{ Visionare } \\
\hline 1. Way Director & 0,755 & 0,005 \\
\hline 2. Agent of Change & 0,743 & 0,005 \\
\hline 3. Spokesman & 0,810 & 0,005 \\
\hline 4. Good coach & 0,804 & 0,005 \\
\hline \multicolumn{3}{|l|}{ Servant leadership } \\
\hline 1. serving-oriented & 0,605 & 0,005 \\
\hline 2. Build follower & 0,660 & 0,005 \\
\hline 3. team work & 0,775 & 0,005 \\
\hline 4. Build trust & 0,643 & 0,005 \\
\hline 5. Brave to decide & 0,767 & 0,005 \\
\hline 6. Preparing surrogate & 0,690 & 0,005 \\
\hline 7. Give responsibility & 0,717 & 0,005 \\
\hline 8. Being role model & 0,590 & 0,005 \\
\hline
\end{tabular}


Table 1 shows that there is significant relation among whole leadership model element and planned leadership model

\section{c. Multyvariate analysis}

\section{Modelling}

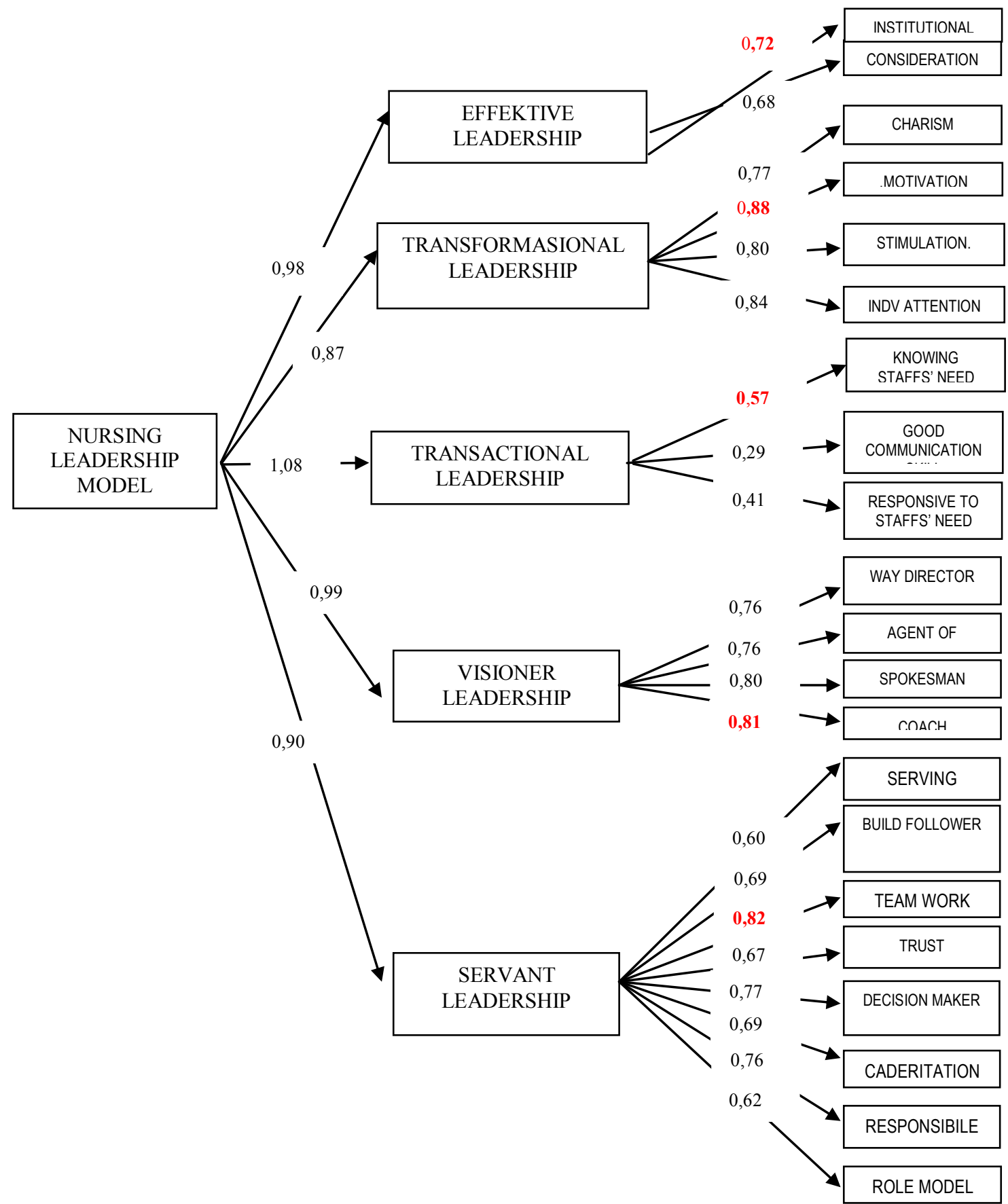

Diagram 1. Standard Coeficient Score Result CFA analysis SEM

Diagram 1 above describes as:

Effective leadership model from standard coeficient score shows that institutional and consideration so effective that effective model positively support developed leadership model 0,98 .

Transformational leadership model from standard coeficient score shows that charism, inspirational motivation, intelectual stimulation and individual attention positively support transformational model. Transformational model positively support developed leadership model 0,87 . 
Transactional leadership model from standard coeficient score shows that good communication knowing and responsive to employees' needed positively support transactional model. Transactional model positively support developed leadership model 1,08.

Visioner leadership model from standard coeficient score shows that good way director, change agent, spokesman and coach positively support visioner model. Visioner model positively support developed leadership model 0,99.

Servant leadership from standard coeficient score shows that serving-oriented, building-follower, team work, trust, decision maker, prepare surrogate, give responsibility, being a role model positively support Servant Leadership. servant leadership model positively support developed leadership model 0,90 .

As a whole, from standard coeficient score shows that effective model, transformational, transactional, visioner and servant leadership positively support developed leadership model.

By modelling interpretation, final Indonesia nursing leadership model can be formulated as: model which is consisted of five leadership models including visioner, effective, transformational, transactional and servant leadership model (VETTS).

Expected leader attitude on developed model based on statistical counting and also functioned as competency criteria are mentioned below:

1. Good coach for staff

2. Inspirational motivation

3. Team building and team work

4. Institutional structured

5. Knowing staffs'needs

\section{Discussion}

Developing model named Indonesia nursing leadership model is developed from five leadership model and 21 elemenet of leadership model. This study results in Effective Leadership Model, Transformational Leadership Model, Transaction Leadership Model, Visioner Leadership Model and Servant Leadership Model supports developed nursing leadership model. The biggest element which support nursing leadership model is preparing surrogate with standard coeficient $0.8,0$ while the least one is skillfull on giving salary 0,03 .

Those five model have significant relation with developed leadership model, but the most influence one is visioner leadership model. The result of modelling will be explained more detailed as below:

\section{Effective Leadership Model}

The result shows most of head nurse support the whole element effective leadership model. Based on SEM analysis, standard coeficient and institution t-test score and consideration support effective leadership model and positively supported developed leadership model.

Effective leader is a leader who manages their organization establishment structurally, having good friendship, trust building, paying attention and kind to their staff. Simply, effetive leadership model support assumption that effective leader is a leader who are able to integrate both aspect organization and humanity in their organization.

\section{Transformational Leadership Model}

The result shows that most of head nurse support whole transformational leadership model element. Based on SEM analysis, standard coeficient and institution t-test score, charism, inspirational motivation, intelectual stimulus, and paying individual attention positively support transformational model and developed leadership model.

Bryman (Burns, 2010) mention transformational as a new leadership, while Sarros dan Butchatsky (Burns, 2010) called as breakthrough leadership. It is called breakthrough because this kind of leader bring any big changes to individu and organization by: reinvent individual self-character within organization or organization reforming, and then start to create inovation. Moreover, this kind leader will take a look at organization structure, process and values to make it better and more relevant, by more interesting way and challange the whole involved par, and try to make organization goal become reality which seems impossible before (Burns, 2010).

\section{Transactional Leadership Model}

The result shows most of head nurses less support transactional leadership model. Based on SEM analysis, good communication, knowing and responsive to staffs' needs positively support transactional model and developed leadership model. 
Lensufiie (2010) said that transactional leadership is contractual leadership between leader and their follower. Leader needs follower and offers something to pay their follower loyalty. The follower eager to take part because of something they want to catch up as reward.

This result similiar with Bass (1990) dan Yukl (1998), which said that relation of transactional leader and their staff shows in three ways: leader who know staff needs and explain what they get if they do good working performance; leaders return the staffs' effort with appopriate salary; and being responsive on staffs' personal needs if it is comparable with what they have done for institution.

\section{Visioner Leadership Model}

The result shows most of head nurses support visioner leadership model element. Based on SEM analysis, standard coeficient and institution t-test score, good way director, change agent, spokesman and coach skill positively support transactional model and developed leadership model. As a whole, visioner leadership model is the main component to construct leadership model, then coaching and preparing surrogate model become most important element on supporting nursing leadership model. Based on this result, it can be concluded that by running visioner leadership model smoothly, the leadership skill will be better.

\section{Servant Leadership Model}

The result shows most of head nurses support servant leadership model element. Based on SEM analysis, standard coeficient and institution t-test score, serving-oriented, building follower, team work, trust maintain, decision maker, prepare surrogate, give responsibility,being role model positively support servant leadership model and developed leadership model.

Greeleaf emphasize servant leadership model is leadership which grows up from serving, great leader is great servant (Meryl, 2006). Servant leadership model different from other model, particularly on the point of the leader response to staffs' need. This approach can be found while the leader respect, pay attention and motivate their follower (McCrimmon, 2010).

\section{Conclusion}

\section{Conclusion And Recommendation}

1. Developed leadership model, is positively supported by visioner, effective, transformational, transactional, and servant leadership model along with its elements.

2. Visioner leadership model is the most important component supporting developed leadership model

3. Expected Head nurse attitude in class A-Hospital: good coach for their staff, providing challenge and significancy of their staffs' working performance, team building and team work, define and arrange group interaction, organize group activities in order to reach organization goal and knowing staffs' need.

\section{Recommendation}

1) Nursing Care

a) For Hospital Director, this reaserch can be use to evaluate head nurse working performance or staffing head nurse in class A-Hospital

b) For Head of Nursing Department class A-Hospital, as an effort to improve nursing care quality, they need to gain their knowledge and leadership skill by formal and informal education as training for improving clinical working performance management, professional nursing care system, and nursing leadership management.

c) Head nurse in class A-Hospital should improve their leadership skill by any training, especially nursing leadership management training

d) Nurse practitioner participation in class A-Hospital is needed for Head Nurse leadership skill application because leadership is collaboration between head nurse and nurse practitioners in order to deliver best nursing care.

2) Nursing Education Instituion

a) As an effort to improve nursing care quality, this research is applicable and can be refference for nursing leadership management

b) This research can be refference for nursing leadership management science by changing material within curriculum which results on leadership competency as developed nursing leadership model.

3) Nursing research and Development

a) Phenomenology qualitative research stage on this research is improved to be grounded theory so it can be more perfect model material. 
b) This reasearch only involving 13 class A-Hospital in Indonesia, moreover, more hospital involved which covering any class is expected on the following study.

c) Examine leadership model effectivity on nurse practitioner working perfromance in class A-Hospital ward during delivering nursing care to client and its effect to client satisfaction.

\section{Acknowledgments}

Many thanks to Director Politehnik Kesehatan Republik Indonesia di Malang, Prof.Dra. Elly Nurrachmah, DNSc.RN.,Dr. Ratna Sitorus, MApp.Sc., Dr. Ede Surya Darmawan,SKM.MDM. who have help this research well conducted.

\section{References}

[1] Alannah, E.R. \& Mark, A.G. (2004). Dimensions of transformational leadership: Conceptual and empirical extensions.

[3] Amadeo, C.A. (2008). A correlational study of servant leadership and registered nurse job satisfaction in acute health-care settings. Doctoral dissertation - research, University of Phoenix; Ed.D. (184 p).

[4] Anderson, S.(2007). Nursing department heads' transformational and transactional leadership: Relationships to nursing faculty satisfaction, willingness to exert extra effort, and perceived department head effectiveness. Journal of Nursing Informatics, Spring; 11(1): $9 \mathrm{p}$

[5] Bernadette, D.(2008). Impact of clinical leadership development on the clinical leader, nursing team and care-giving process: A case study. Journal of Nursing Management, 16, 753-763DOI: 10.1111/j.1365-2834.2008. 00930.x

[6] Bolden, R., Gosling, J., Marturano, A., \& Dennison, P. (2003), A review of leadership theory and competency frameworks. Journal Servant Leadership Centre for Leadership Studies. United Kingdom: University of Exeter.

[7] Bowles (2008), a comparative study of transformational leadership in nursing development units and conventional clinical settings. Journal of Nursing Management.

[8] Burn, M. (2010). Leadership. $2^{\text {nd }}$ Ed. New York: Harper Collins.

[9] David, W.S.(2006). Introductory statistics: Concepts, models, and applications. Psychological Statistics at Missouri State University, www.psychstat. missouristate. edu.

[10] Departemen Kesehatan R.I (2006). Panduan Nasional Keselamatan Pasien Rumah Sakit. Jakarta: Bhakti Husada

[11] Depertemen Kesehatan R.I (2006). Upaya peningkatan mutu pelayanan rumah sakit. (konsep dasar dan prinsip). Direktorat Jendral Pelayanan Medik Direktorat Rumah Sakit Khusus dan Swasta.

[12] Downs, F.C. (2007). The servant-leadership worldview in long-term care nursing. Annals of Long Term Care 15(8): 36-9 (15 ref).

[13] Failla, K.R., \& Stichler, J.F. (2008). Manager and staff perceptions of the manager's leadership style. Journal Nurs Adm. Nov, 38(11):480-7.

[14] Finkelman, A.W. (2006). Leaderships and managemen in nursing. New Jersey: Pearson Prentice Hall

[15] Garber, J.S., Madigan, E.A., Click, E.R., \& Fitzpatrick, J.J.(2009). Attitudes towards collaboration and servant leadership among nurses, physicians and residents. Journal of Interprofessional Care; 23(4): 331-40 (21 ref).

[16] Jackson, D. (2008). Servant leadership in nursing: a framework for developing sustainable research capacity in nursin. Collegian; 15(1): 27-33 (23 ref).

[17] James, C.S., \& Joseph, C.S. (2001). The transformational-transactional leadership model in practice. Leadership \& Organization Development Journal, Vol. 22 Iss: 8, pp.383- 394

[18] Jenkins, M., \& Stewart, A.C. (2010). The importance of a servant leader orientation, Health Care Management Review; 35(1): 4654 (43 ref).

[19] Johan, (2011). Studi Deskriptif : Harapan perawat pelaksana terhadap model kepemimpinan yang diterapkan kepala ruangan di Rumah sakit negeri dan swasta di Jakarta, tidak diterbitkan.

[20] John, D.P. (2004). Transformational and transactional leadership predictors of the 'stimulant' determinants to creativity in organisational work. Electronic Journal of Knowledge Management. Volume 2 Issue 22004 (23-34), Environments Higher Colleges of Technology, Dubai: United Arab Emirates.

[21] Marquis, B. L. \& Huston, C.J. (2009). Leadership roles and management functions in nursing. California : Lippincott

[22] Meryl Roth Gersh, PT, MMSc, (2006), Servant-leadership: A philosophical foundation for professionalism in physical therapy. Journal of Physical Therapy Education, Vol 20, No 2.

[23] Moleong, J.L. (2010). Metodologi penelitian kualitatif. Bandung: Remaja Rosdakarya Offset.

[24] Neill, M.W. \& Saunders, N.S. (2008). Servant leadership: Enhancing quality of care and staff satisfaction. Journal of Nursing Administration. 38(9): 395-400 (19 ref).

[25] Sanusi, A., \& Sutikno, S. (2009). Kepemimpinan sekarang dan masa depan. Bandung: Prospect.

[26] Sastroasmoro, S.,\& Ismael,S. (2011). Dasar-dasar metodologi penelitian klinis. Jakarta: Sagung seto.

[27] Sellgren, S.F., Ekvall, G., \& Tomson, G (2008). Leadership behaviour of nurse managers in relation to job satisfaction and work climate. Journal of Nursing Management, Jul; 16(5): 578-87 (58 ref).

[28] Sellgren, S.F., Ekvall, G., \& Tomson, G. (2006). Leadership styles in nursing management: Preferred and perceived, Journal of Nursing Management, Jul;14(5):348-55.

[29] Sjetne I.S., Veenstra M., Ellefsen B. \& Stavem K. (2009). Service quality in hospital wards with different nursing organization: Nurses' ratings. Journal of Advanced Nursing. 65(2), 325-336, doi: 10.1111/j.1365-2648.2008.04873.x

[30] Spinelli, R.J. (2006). The applicability of bass's model of transformational, transactional, and laissez-faire leadership in the hospital administrative environment. Research and Perspectives on Healthcare, Copyright (C) 2006 Heldref Publications.

[31] Stordeur (2000). Leadership styles across hierarchical levels in nursing departments. Nursing Research, - journals.l ww.com Lippincott Williams \& Wilkins, Inc.

[32] Susan \& Joan (2000). Transformational leadership: The development of a model of nursing case management by the army nurse corps. January/February 2000 Articles Nursing Research: - Volume 49 - Issue 1 - pp 37-43.

[33] Swansburg \& Swansburg. (1999). Introductory management and leaderships for nurses. Second edition. Jones and Barttlet Publishers : Boston.

[34] Swansburg, R.C. (1999). Introductory management and leadership for clinical nurses: an interactive text . $2^{\text {nd }}$ ed. Canada : Jones and Bartlett Publisher. 
[35] Vecchio, R.P.,\& Pearce (2008). The utility of transactional and transformational leadership for predicting performance and satisfaction within a path-goal theory framework, Journal of Occupational and Organizational Psychology, Volume: 81, Issue: 1, Publisher: Wiley Online Library, Pages: 71-82

[36] Waterman, H. (2011). Principles of 'servant leadership' and how they can enhance practice. Jurnal nursing management, February 2011, Volume 17, Number 9. 